\title{
Protein Heterogeneity in the Human Ro/SSA Ribonucleoproteins The 52- and 60-kD Ro/SSA Autoantigens Are Encoded by Separate Genes
}

\author{
Kazuko Itoh, Yasuhiko Itoh, and Mark Barton Frank \\ Arthritis and Immunology Program, Oklahoma Medical Research Foundation, Oklahoma City, Oklahoma 73104
}

\begin{abstract}
Two cDNA clones encoding the 52-kD form of a protein present in human Ro/SSA ribonucleoprotein complexes were cloned from a $\lambda$ gt11 human thymocyte cDNA library. These clones reacted with lupus patient sera which had anti-52-kD Ro/SSA antibodies, and with affinity-purified anti-52-kD Ro/ SSA antibodies. Moreover, affinity-purified antibodies isolated from isopropyl- $\beta$-D-thiogalactopyranoside-induced proteins of these clones reacted only with the 52-kD protein of lymphocytes in Western blots and precipitated Ro/SSA hY RNAs, confirming that the clones encode a 52-kD Ro/SSA antigen.

The cDNA contains a single open reading frame of 1,425 nucleotides and encodes a predicted 475-amino acid polypeptide with a molecular mass of $54,108 \mathrm{D}$. This protein appears unique in that both a zinc finger and leucine zipper motif are present on this protein. Surprisingly, no homology was found between the 52-kD Ro/SSA gene or protein and three published 60-kD Ro/SSA sequences. However, significant similarity of the 52-kD Ro/SSA was detected with human rfp and mouse rpt-1. These three proteins each contain similar zinc finger motifs in approximately their first 145 amino acid residues. The cDNA and the protein expressed therefrom are useful in the analysis of the structural and functional properties of this autoantigen. (J. Clin. Invest. 1991. 87:177-186.) Key words: autoimmunity $\bullet$ human autoantigen nucleotide sequence - systemic lupus erythematosus
\end{abstract}

\section{Introduction}

Ro/SSA is a ribonucleoprotein particle composed of a single polypeptide and one of four small RNA molecules (1-3). It is present in all mammalian cells studied but has no known function. The antigenic portions of the Ro/SSA particle reside on the polypeptide chain (4). Autoantibodies to Ro/SSA are found in the sera of $30-50 \%$ of patients with systemic lupus erythematosus (SLE) ${ }^{1}$ and in at least $50 \%$ of patients with primary Sjogren's syndrome $(3,5)$. These autoantibodies occur in a higher percentage in patients with subacute cutaneous lupus erythematosus, and in essentially all neonatal lupus erythematosus patients with congenital heart block $(6,7)$. The presence of

Address reprint requests to Dr. Frank, Arthritis and Immunology Program, Oklahoma Medical Research Foundation, 825 NE 13th Street, Oklahoma City, OK 73104.

Received for publication 25 May 1990 and in revised form $12 \mathrm{Au}$ gust 1990.

1. Abbreviations used in this paper: IPTG, isopropyl- $\beta$-D-thiogalactopyranoside; SLE, systemic lupus erythematosus.

J. Clin. Invest.

(c) The American Society for Clinical Investigation, Inc. $0021-9738 / 91 / 01 / 0177 / 10 \quad \$ 2.00$

Volume 87, January 1991, 177-186
anti-Ro/SSA antibodies is associated with lymphopenia, photosensitive dermatitis, pulmonary disease, and renal disease in lupus patients (8-13), suggesting a pathogenic role for these antibodies in this disease.

Recent studies have shown heterogeneity in the molecular structure of the Ro/SSA antigen. Anti-Ro/SSA antibodies from SLE patients eluted from Western blots of human lymphocyte extracts indicate that a 60 - and $52-\mathrm{kD}$ protein are associated with the $h Y$ Ro/SSA RNAs in nucleated cells $(14,15)$. In human red blood cells, Ro/SSA particles contain either a 60 - or 54-kD polypeptide. Immunoprecipitation of these particles reveals that they associate with only a subset of the hY RNAs (15).

Studies from our laboratory have shown that the $60-\mathrm{kD}$ Ro/SSA polypeptides in lymphocyte and red blood cell are distinct but related. Most patient autoantibodies which bind to the 60-kD Ro/SSA lymphocyte polypeptide cross-react with the $60-\mathrm{kD}$ red blood cell Ro/SSA polypeptide. However, certain patients produce antibodies that recognize only one form of this protein. Similarly, antibodies binding to the lymphocyte 52-kD Ro/SSA polypeptide cross react in most but not all cases with the red blood cell 54-kD Ro/SSA protein. Thus, the four isoforms of Ro/SSA fall into two non-cross-reacting families (16).

The majority of biochemical studies of Ro/SSA polypeptides have centered around the analysis of the $60-\mathrm{kD}$ containing particles. Although Western blot analyses using different patient sera and tissue extracts show no evidence for heterogeneity in the $60-\mathrm{kD}$ proteins, three different sequences of the gene encoding 60-kD Ro/SSA have been reported. Two of them differ only in the region encoding the carboxy-terminal amino acid residues $(17,18)$; the third is entirely different from these two sequences (19). To determine the relationship between the 60 - and 52-kD Ro/SSA proteins, we have cloned a gene which encodes the human 52-kD form of the Ro/SSA protein. In this study, we report the sequence of this gene and show that it is unique from the reported $60-\mathrm{kD}$ Ro/SSA genes. The 52-kD Ro/SSA polypeptide is not a degradation product of the $60-\mathrm{kD}$ form, consistent with the lack of immunological cross-reactivity between these proteins. Furthermore, the 52$\mathrm{kD}$ Ro/SSA gene encodes both zinc finger and leucine zipper motifs, both of which have been implicated in nucleic acid and protein interactions. This study demonstrates further the considerable heterogeneity that exists in the Ro/SSA autoantigenic particles, and has important implications in the generation of an autoimmune response to Ro/SSA in patients with certain rheumatic diseases.

\section{Methods}

Adsorption of Escherichia coli antibodies. Sera from patients with systemic lupus erythematosus (20) and controls were adsorbed against $E$. coli after lysis with the bacteriophage vector $\lambda$ gt 11 to deplete naturally occurring anti-E. coli antibodies. Briefly, five petri dishes with 30,000- 
50,000 plaque-forming units (pfu) were plated with $E$. coli strain $Y 1090$ cells on $\mathrm{LB}$ agar and grown for $3.5 \mathrm{~h}$ at $42^{\circ} \mathrm{C}$. The cultures were overlaid with a single nitrocellulose filter for $3 \mathrm{~h}$ on one side and $2 \mathrm{~h}$ on the other side at $37^{\circ} \mathrm{C}$. Filters were washed in TBST $(50 \mathrm{mM}$ Tris- $\mathrm{HCl}$, pH $8.0,150 \mathrm{mM} \mathrm{NaCl}$, and $0.05 \%$ Tween-20), and then sequentially incubated at room temperature with a 1:100 dilution of human serum. Adsorptions were monitored by exposing a small piece of each filter with an alkaline phosphatase-conjugated, goat anti-human IgG antisera (Sigma Chemical Co., St. Louis, MO). The sections of these filters were then reacted with nitro blue tetrazolium (NBT) and 5-bromo-4chloro-3-indolyl-phosphate (BCIP) according to the ProtoBlot system (Promega Biotec, Madison, WI).

Screening a human cDNA library. A human thymocyte cDNA library cloned in the $\lambda$ gt 11 expression vector was obtained from Clontech Laboratories, Palo Alto, CA. 30,000 pfu per petri dish were plated with $E$. coli $\mathrm{Y} 1090$ cells on LB agar. The partially lysed $E$. coli lawn was overlaid for $3 \mathrm{~h}$ at $37^{\circ} \mathrm{C}$ with a nitrocellulose membrane which had previously been soaked in $10 \mathrm{mM}$ isopropyl- $\beta$-D-thiogalactopyranoside (IPTG). Filters were washed in TBST, incubated with an $E$. coli-absorbed patient serum which contained antibodies to the $52-\mathrm{kD} \mathrm{Ro} / \mathrm{SSA}$ protein, and screened using the alkaline phosphatase method described above. Blue-colored plaques were purified using the same patient serum.

Affinity purification of antibodies from patient serum. Antibodies were affinity-purified from two sources using either nitrocellulose membranes from $(a)$ Western blots of polyacrylamide gel-separated human lymphocyte extracts, or $(b)$ blots of IPTG-induced proteins from plaque purified bacteriophage clones. Lymphocytes were lysed by sonication in water and centrifuged to remove debris. Supernatants were reduced, heat-denatured, and subjected to electrophoresis on a $10 \%$ polyacrylamide gel. Proteins were electrophoretically transferred to nitrocellulose membranes (21). To localize the region of the filter containing $52-\mathrm{kD}$ proteins, a small section of the membrane was reacted with serum from a patient containing anti-52-kD Ro/SSA autoantibodies. Binding of patient antibodies was detected as described above. The corresponding section of the remainder of the membrane was then excised and incubated with patient serum using a modification of a method by Krohne et al. (22). Briefly, the membrane was incubated with serum for $30 \mathrm{~min}$ at $37^{\circ} \mathrm{C}$, and the antibodies were eluted with $3 \mathrm{M}$ sodium (vs. potassium) thiocyanate. The elution process was repeated five times and the resulting solution was concentrated $\sim 50$-fold using a Centriprep 30 concentrator (Amicon Division, W. R. Grace, Danvers, MA). Antibodies which bound to $60-\mathrm{kD}$ $\mathrm{Ro} / \mathrm{SSA}$ proteins, or proteins produced in IPTG-induced bacteriophage plaques were eluted in an identical manner.

Immunoprecipitation of Ro/SSA proteins and hY RNAs. Affinitypurified antibodies isolated from IPTG-induced bacteriophage plaques were used to immunoprecipitate nucleic acids bound to Ro/SSA proteins from HeLa cells (23). These antibodies were bound to staphylococcal protein A-coated Sepharose CL-4B beads (Pharmacia, Inc., Piscataway, $\mathrm{NJ}$ ). HeLa cells were lysed by sonication in the presence of $0.05 \%$ NP-40 and mixed with these beads. Bound material was eluted with $0.3 \mathrm{M}$ sodium acetate and $1 \%$ SDS, and subjected to phenol/chloroform extraction. Ethanol precipitated nucleic acids were dissolved in electrophoresis sample buffer and subjected to PAGE in the presence of $7 \mathrm{M}$ urea. Silver staining was used to detect nucleic acids.

Characterization and sequencing of cDNA in bacteriophage clones. DNA was extracted from bacteriophage after pronase digestion. Restriction enzyme digestions were carried out under conditions recommended by the enzyme's suppliers. DNA was subjected to electrophoresis in $0.8 \%$ agarose gels and transferred to nylon membranes (Amersham Corp., Arlington Heights, IL) by the method of Southern (24). Isolated inserts were radioactively labeled with $\left[\alpha-{ }^{32} \mathrm{P}\right] \mathrm{dCTP}$ using random hexamer primers $(25,26)$, and hybridized to nylon membranes in cross-hybridization studies. Following hybridization, membranes were washed under high stringency conditions to $0.1 \times \operatorname{SSPE}(15 \mathrm{mM} \mathrm{NaCl}$, $1 \mathrm{mM} \mathrm{NaH} \mathrm{PO}_{4}, 0.1 \mathrm{mM}$ EDTA, pH 7.0) and $0.1 \%$ SDS at $65^{\circ} \mathrm{C}$. Hybridization was detected by autoradiography.
The cDNA inserts from bacteriophage clones were purified after electrophoresis in $5 \% N, N^{\prime}$-bis-acrylylcystamine cross-linked polyacrylamide gels (Bio-Rad Laboratories, Richmond, CA), reduction with 2mercaptoethanol, and DEAE ion-exchange chromatography. The resulting fragments were subcloned into an EcoRI-digested M13mp19 bacteriophage vector $(27,28)$. Additional DNA from clone FI18.1 was digested with restriction enzymes chosen for their ability to produce DNA fragments which could be directly subcloned into the multiple cloning sites of M13mp19. After ligation of these inserts to the vectors with T4 DNA ligase (Bethesda Research Laboratories, Gaithersburg, MD), DNA was transformed in E. coli strain JM103. Single stranded DNA from M13 subclones was prepared (27) and subjected to nucleotide sequencing using the dideoxy chain-termination method (29) with T7 DNA polymerase (30) (U.S. Biochemical Corp., Cleveland, $\mathrm{OH}$ ). Nucleotide sequences were also determined from deletion subclones produced with T4 DNA polymerase (31).

Computer analyses of nucleotide and amino acid sequences were performed using the Sequence Analysis Software Package of the Genetics Computer Group, University of Wisconsin (32) on a VAX 8250 computer, and with other programs written for use on a Cray Y-MP supercomputer at the Pittsburgh Supercomputing Facility or on a IBM PC, including modification of those described by Schwindinger and Warner (33).

\section{Results}

Isolation of the $52 \mathrm{kD} \mathrm{Ro/SSA}$ cDNA clones. A human thymocyte cDNA library cloned into the bacteriophage vector $\lambda$ gt 11 was screened with the lupus patient serum DU after IPTG induction of the $\beta$-galactosidase gene (Fig. $1 A$ ). Autoantibodies in this serum bind to the 52- but not $60-\mathrm{kD}$ Ro/SSA polypeptide in Western blots of lymphocyte extracts. Two immunoreactive clones were detected from approximately one million pfu which were screened. These clones were plaque purified and have been designated "FI18.1" and "FI19.3." The binding of
A

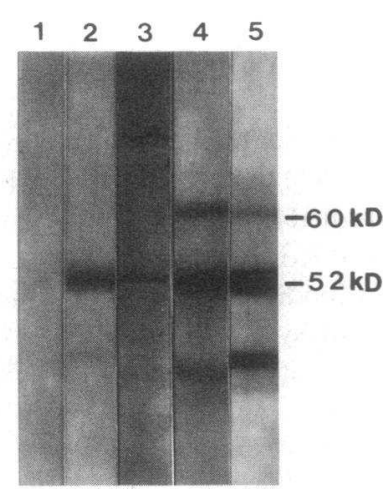

B

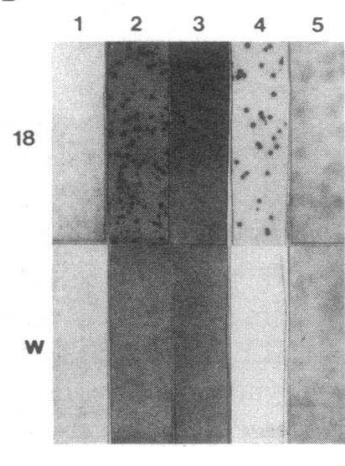

Figure 1. (A) Western blot of human lymphocyte extracts resolved by SDS-PAGE. Section of the nitrocellulose membrane to which the proteins were transferred were incubated with a normal human serum (lane 1 ) and patient sera DU, MO, BO, and DA (lanes 2, 3, 4, and 5 , respectively). The 60 - and $52-\mathrm{kD}$ Ro/SSA proteins are labeled; the lower band in lanes 4 and 5 is the 45-kD breakdown product of the $\mathrm{La} / \mathrm{SSB}$ protein. A summary of autoantibody specificities of these and other patients is listed in Table I. (B) Specific reaction of IPTGinduced proteins of clone FI18.1 (18) and a wild-type $\lambda$ gt 11 clone $(W)$ with SLE patient and control sera. IPTG-induced proteins in bacteriophage plaques were bound to nitrocellulose membranes and incubated with a normal human serum (lane $l$ ), patient sera DU and MO (lanes 2 and 3, respectively), affinity-purified anti-52-kD Ro/ SSA antibody from patient BO (lane 4), and affinity-purified anti60-kD Ro/SSA antibody from patient DA (lane 5). 
DU antibodies to these bacteriophage clones was IPTG dependent, indicating that this reactivity was specific for cDNAencoded epitopes, and not due to bacterial or vector-encoded antigens.

IPTG-induced proteins expressed in these clones were screened with a panel of sera from different SLE patients, with affinity-purified antibodies, as well as with normal human sera. All sera were adsorbed to remove naturally occurring anti- $E$. coli antibodies before use. The autoimmune specificity of five sera tested in this study as detected in Western blots of human lymphocyte extracts is shown in Fig. $1 A$. The reactivity of IPTG-induced proteins in clone FI18.1 with these human sera is shown in the top portion of Fig. $1 \mathrm{~B}$. Lane 2 shows the reactivity detected with serum DU, the serum used in the library screening. Reactivity was also detected with a patient serum (MO) which contains only anti-52-kD Ro/SSA reactivity (lane 3). No reactivity was detected with sera from healthy controls (lane 1 ), or with IPTG-induced $\lambda$ gt 11 infected $E$. coli plaques with any of these sera (bottom panels, Fig. $1 \mathrm{~B}$ ). In all comparisons, qualitative and quantitative levels of reactivity of IPTG-induced proteins of clones FI18.1 and FI19.3 were found to be identical. A summary of all sera tested is summarized in Table I. It is clear from these experiments that autoan-

Table I. Sera Tested

\begin{tabular}{|c|c|c|c|c|c|}
\hline \multirow[b]{2}{*}{ Patient } & \multicolumn{3}{|c|}{ Ro/SSA specificity* } & \multirow{2}{*}{$\begin{array}{c}\text { Other } \\
\text { autoantibodies }\end{array}$} & \multirow{2}{*}{$\begin{array}{c}\text { Clone } \\
\text { reactivity }\end{array}$} \\
\hline & 52 & 54 & 60 & & \\
\hline TU & - & - & + & nRNP & - \\
\hline DV & - & - & +11 & nRNP & - \\
\hline VQ & - & - & + & nRNP & - \\
\hline WS & - & - & + & nRNP & - \\
\hline NE & + & + & + & - & + \\
\hline ST & + & + & + & - & + \\
\hline DS & + & + & + & - & + \\
\hline $\mathrm{CH}$ & + & + & + & - & + \\
\hline TR & + & + & + & $\mathrm{La} / \mathrm{SSB}$ & + \\
\hline BO & + & + & + & $\mathrm{La} / \mathrm{SSB}$ & + \\
\hline BM & + & + & + & $\mathrm{La} / \mathrm{SSB}$ & + \\
\hline DA & + & + & + & La/SSB & + \\
\hline $\mathrm{ME}$ & + & + & + & $\mathrm{La} / \mathrm{SSB}$ & + \\
\hline DU & + & + & - & - & + \\
\hline MO & + & - & - & - & + \\
\hline NHS' & - & - & - & - & - \\
\hline
\end{tabular}

* The size of the Ro/SSA polypeptide detected in Western blots using different patient sera are shown. The 52- and $60-\mathrm{kD}$ forms of the Ro/SSA proteins are detected in extracts of human lymphocytes. The 54-kD Ro/SSA protein is detected in extracts of human red blood cells. + , detection of an antibody which binds to the particular antigen; -, indicates no antibody to that antigen was detected.

${ }^{\ddagger}$ Antibodies to other ribonucleoprotein complexes include those which bind to $\mathrm{La} / \mathrm{SSB}$ and $\mathrm{nRNP}$. The presence of these antibodies has been detected either by Ouchterlony immunodiffusion, Western blot analyses, or ELISA.

Antibodies were tested against IPTG-induced proteins expressed by clone FI18.1.

" Reacts with the 60-kD Ro/SSA in red blood cells but not with the 60-kD Ro/SSA in nucleated cells.

' NHS, normal human serum. No autoantibodies to the specificities tested were detected in sera from four healthy individuals. tibody reactivity with IPTG-induced recombinant proteins is absolutely correlated only with reactivity to $52-\mathrm{kD}$ Ro/SSA protein. These data suggest the cDNA in these clones encode an epitope present on the 52- but not the $54-$ or $60-\mathrm{kD}$ Ro/SSA protein.

It is possible that antibodies in the sera used above were binding to epitopes in these clones not detected in Western blots. In order to test this possibility, antibodies from either BO or DA were eluted (22) from the 45-, 52-, and $60-\mathrm{kD}$ regions of Western blots of human lymphocyte extracts. Antibodies which were affinity purified from the $52-\mathrm{kD}$ region of human lymphocyte extracts bound to the IPTG-induced proteins in this clone (Fig. $1 B$, lane 4 ). However, affinity purified anti-60$\mathrm{kD}$ antibodies failed to bind to either clone (lane 5), strongly suggesting that the cDNA encoded epitopes are present on 52but not $60-\mathrm{kD}$ Ro/SSA polypeptides. Antibodies eluted from the 45-kD La/SSB area of the Western blot also failed to bind to proteins expressed in these clones (data not shown).

IPTG-induced proteins of clones FI18.1, FI19.3, and wildtype $\lambda$ gt 11 were blotted to nitrocellulose filters. These filters were exposed to $E$. coli-adsorbed DU serum, and bound antibodies were eluted with $3 \mathrm{M} \mathrm{NaSCN}$. Fig. 2 shows the results of Western immunoblotting of human lymphocyte extracts with these affinity-purified antibodies. DU serum antibodies bind to the 52-kD form of Ro/SSA (lane 1). Affinity-purified antibodies from this patient which were eluted from IPTG-induced clones FI18.1 and FI19.3 reacted specifically with a 52-kD lymphocyte protein (lanes 2 and 3, respectively). Antibodies eluted from IPTG-induced $\lambda$ gt 11 plaques failed to bind with this protein demonstrating the clonal specificity of this reaction (lane 4). The most parsimonious explanation for these findings

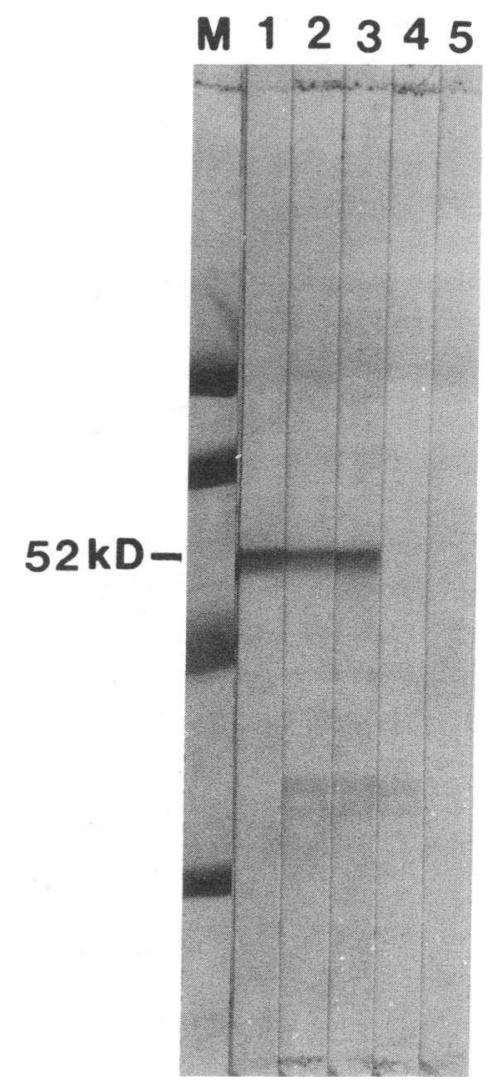

Figure 2. Characterization of affinity-purified antibodies isolated from IPTG-induced proteins of clones FI18.1 and FI19.3. Human lymphocytes extracts were separated by SDS-PAGE and transferred to a nitrocellulose membrane. Protein molecular mass markers are shown in lane $M$ (Pharmacia, Inc.,) from high to low molecular mass: phosphorylase b (94 kD), bovine serum albumin (67 kD), ovalbumin (43 kD), carbonic anhydrase (30 kD). The Western blot was developed with patient DU serum (lane 1), affinity purified antibodies isolated from IPTG-induced proteins of clones FI18.1, FI19.3 and a wild-type $\lambda$ gt 11 clone (lanes 2-4, respectively), and normal human serum (lane 5). 
is that a similar epitope exists on the $52-\mathrm{kD}$ Ro/SSA protein and the cDNA-encoded protein. To further test this hypothesis, this experiment was repeated using serum from patient DA which contains not only anti-52-kD Ro/SSA antibodies, but also anti-60-kD Ro/SSA antibodies and anti-La/SSB antibodies. Antibodies eluted from clone FI18.1 reacted only with a 52-kD protein (data not shown); no anti-60-kD Ro/SSA or anti-La/SSB activity was detected, confirming the specificity of antibodies eluted from such membranes.

If this cDNA encodes the 52-kD Ro/SSA protein, a lysate of this clone should specifically block the anti-52- but not the anti-60-kD Ro/SSA reactivity detected on Western blots of human lymphocyte extracts. $E$. coli infected with either clone FI18.1 or $\lambda$ gt 11 wild-type bacteriophage were grown in 1 liter of culture with IPTG to maximal optical density. The cells were washed, resuspended in $10 \mathrm{ml}$ of water, and lysed with lysozyme and sonication. These lysates were treated with 12.5 U of DNAase I to reduce viscosity and subsequently used as blocking agents in Western blots of human lymphocytes treated with sera containing both anti-52- and anti-60-kD Ro/ SSA antibodies. Blocking of the anti-52- but not anti-60-kD Ro/SSA antibodies was observed only with lysates from the recombinant clone indicating a lack of cross-reactivity between the recombinant protein and the $60-\mathrm{kD}$ form of Ro/SSA.

To determine if the $52-\mathrm{kD}$ protein detected in the previous experiment is present in a Ro/SSA ribonucleoprotein particle, affinity-purified antibodies from clones FI18.1 and FI19.3 were used to immunoprecipitate particles from HeLa cells. After phenol extraction to remove proteins from the immunoprecipitated material, denaturing PAGE was performed to characterize nucleic acids that might be present in the samples. Fig. 3 shows that all hY Ro/SSA RNAs were found only when particles were immunoprecipitated with affinity-purified antibodies from clones FI18.1 and FI19.3. Small RNAs associated with $\mathrm{La} / \mathrm{SSB}$ were not precipitated by these affinity purified antibodies, and no hY RNAs were observed using antibodies which were affinity-purified from wild-type $\lambda$ gt 11 transfected $E$. coli cells or serum from a healthy control. These results suggest that the $52-\mathrm{kD}$ proteins detected on Western blots are proteins present in Ro/SSA particles and that the cDNA inserts of clone FI18.1 and FI19.3 encode at least a portion of this protein.

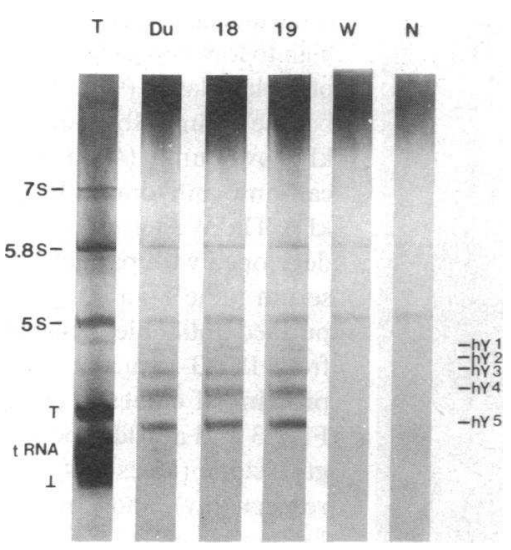

Figure 3. Silver stain of a $7 \mathrm{M}$ urea, $10 \%$ polyacrylamide gel of RNAs immunoprecipitated from HeLa cells. Total HeLa cell RNA is shown in the first lane (T). RNAs were immunoprecipitated with patient DU serum (lane $D u$ ), antibodies affinity-purified from IPTG-induced protein of clones FI18.1, FI19.3, and a wild-type $\lambda$ gt 11 $(18,19$, and $W$, respectively), and a normal human serum $(N)$.
Characterization of the bacterially expressed Ro/SSA proteins. IPTG-induced proteins in clones FI18.1 and FI19.3 were further examined. Lysogens were constructed for each clone in $E$. coli strain Y1089. After IPTG induction, crude bacterial lysates were resolved in $7.5 \%$ SDS-polyacrylamide gels, transferred to nitrocellulose filters, and developed with either a mouse anti- $\beta$-galactosidase monoclonal antibody, DU patient serum, affinity-purified anti-52-kD Ro/SSA antibodies, or normal human sera. If the cDNA in clones FI18.1 or FI19.3 encoded a full-length polypeptide, a $168-\mathrm{kD} \beta$-galactosidase fusion protein was predicted when screened with either DU serum or the mouse anti- $\beta$-galactosidase antibody. Fig. 4 shows that bands close in size to the native $\beta$-galactosidase, and its degradation products, were detected with mouse anti- $\beta$-galactosidase antibodies. When using DU serum, a 48-50-kD band was unique to clones FI18.1 and FI19.3. A faint band $\sim 160 \mathrm{kD}$ specific to these clones was detected only with patient antibodies. The lack of reactivity of a similarly sized faint band detected with anti- $\beta$-galactosidase antibodies makes it questionable as to whether this weak band is a blotting artifact or an example of a $\beta$-galactosidase fusion protein which is produced and rapidly cleaved in these cells to yield two polypeptides, one approximately the size of $\beta$-galactosidase and the other just slightly smaller than the expected size of the 52-kD Ro/SSA protein. Anti-52-kD Ro/SSA affinity-purified antibodies eluted from Western blots of lymphocyte extracts bound to the this $50-\mathrm{kD}$ protein expressed in these bacteria. Furthermore, antibodies eluted from the $50-\mathrm{kD}$ protein expressed in bacteria bound specifically to a 52-kD lymphocyte protein and immunoprecipitated the Ro/SSA hY RNAs (not shown). All of these findings are consistent with the cDNA insert in each clone encoding the $52-\mathrm{kD}$ Ro/SSA protein.

Sequence analysis of the 52-kD Ro/SSA cDNA clones. Bacteriophage DNA from clones FI18.1 and FI19.3 was digested with EcoRI, subjected to electrophoresis, and stained with ethidium bromide to determine the size of the cDNA inserts in

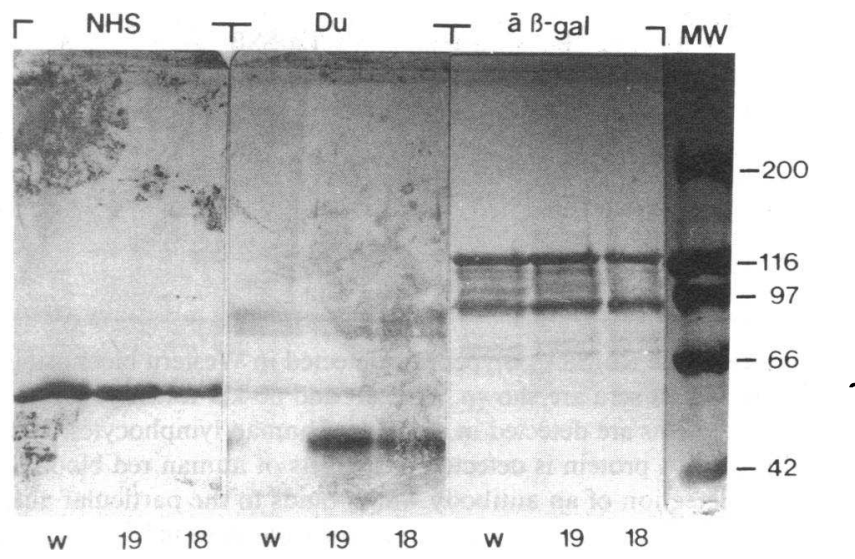

Figure 4. Western blot analysis of proteins expressed in E. coli lysogens. Lysogens from clone FI18.1, clone FI19.3, and a wild-type $\lambda$ gt 11 clone, designated 18,19 , and $W$, respectively at the bottom of the figure are shown following separation in a 7.5\% SDSpolyacrylamide gel and transfer to a nitrocellulose membrane. The membrane was probed with normal human serum $(N H S)$, DU patient serum, or a mouse anti- $\beta$-galactosidase antibody ( $\overline{\mathbf{a}} \beta$-gal). Sizes of protein molecular mass markers in kilodaltons are shown to the right of the figure. 

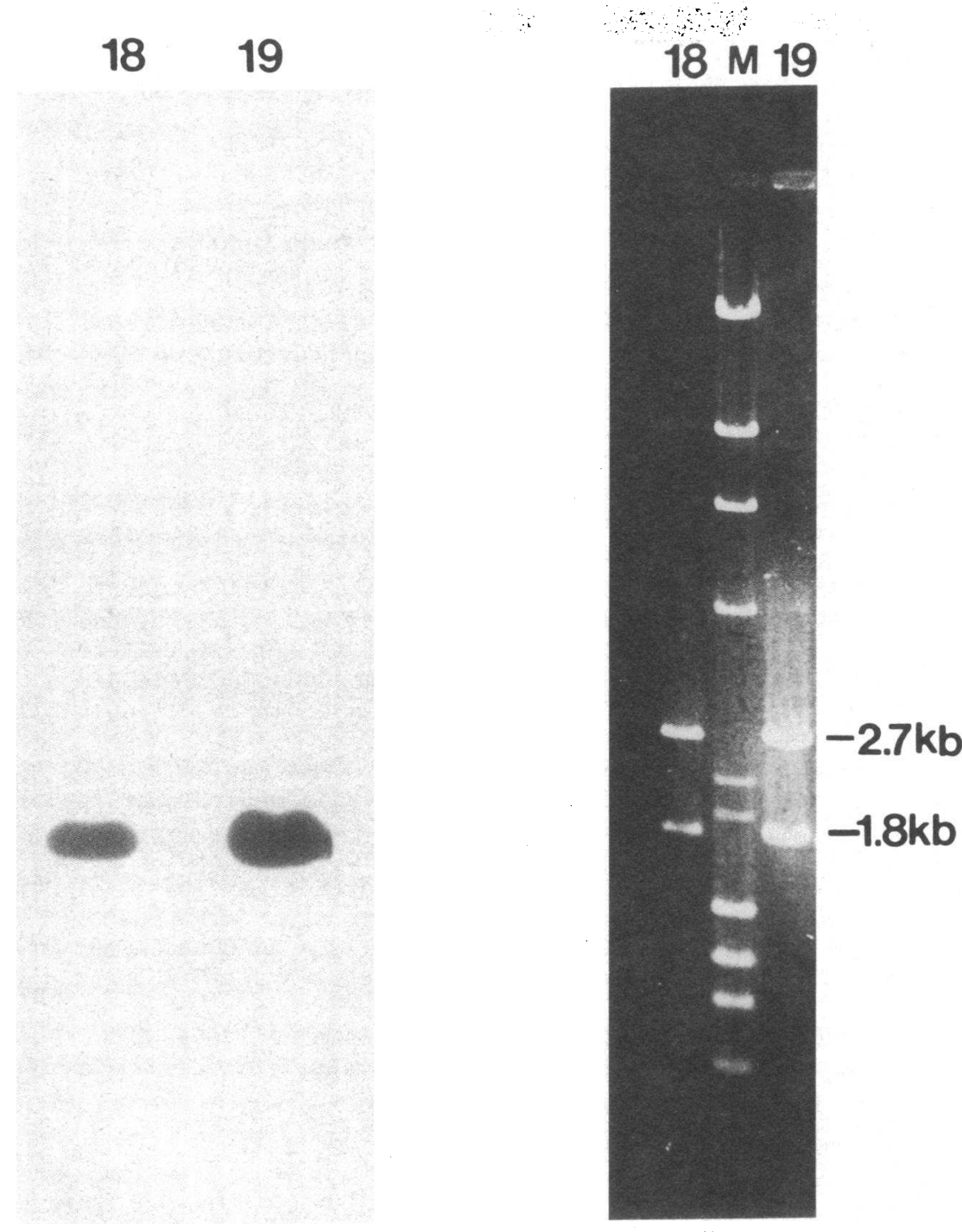

Figure 5. Southern blot hybridization of isolated cDNAs. cDNAs from clones FI18.1 (18) and FI19.3 (19) were subcloned into the pUC19 vector, digested with $E c o$ RI, and electrophoresed in a $\mathbf{0 . 8 \%}$ agarose gel (right). DNA was transferred to a nylon membrane (24) and hybridized to radiolabeled clone FI18.1 cDNA. Hybridization was detected with autoradiography (left).

these clones. A single $1.8-\mathrm{kb}$ insert was present in each clone. Inserts from both clones were isolated and subcloned into the plasmid pUC19 (28). Similarity in the nucleotide sequence of these cDNAs was demonstrated in the following ways. First, DNA from each plasmid subclone was digested with EcoRI, subjected to electrophoresis in a $\mathbf{0 . 8 \%}$ agarose gel, and transferred to a nylon membrane using the method of Southern (24). The isolated 1.8-kb insert from clone FI18.1 was radiolabeled $(25,26)$ and hybridized to this Southern blot. Fig. 5 shows cross hybridization between this probe and the insert from each clone. Secondly, products of restriction enzyme digestions of each insert with seven restriction enzymes were subjected to electrophoresis in polyacrylamide gels. Ethidium bromide staining of these fragments revealed no apparent differences between these clones (data not shown).

The FI18.1 and FI19.3 cDNAs were each subcloned into the M13mp19 bacteriophage vector (28) and their nucleotide sequence was determined using the method of Sanger et al. (29). No differences in the terminal sequences of FI18.1 and FI19.3 were detected. The complete nucleotide sequence of clone FI18.1 was determined from both strands and is shown in Fig. 6. A single open reading frame of 1,425 nucleotides extends from a methionine codon (ATG) at position 39 to a stop codon (TGA) at position 1464 . The nucleotide sequence adjacent to this initiation codon is consistent with an optimal eukaryotic consensus sequence for initiation of translation (34, 35 ). The coding region is followed by a 3 ' untranslated region characterized by numerous stop codons in all reading frames and a putative polyadenylation signal (AATAAA) at position 1827. If the EcoRI site at the 5 ' end of this CDNA was ligated to the $E c o$ RI site of the lacZ gene of $\lambda$ gt 11 , the $52-\mathrm{kD}$ Ro/SSA cDNA would be out of frame with $\beta$-galactosidase. Therefore, we hypothesize that a small number of additional bases were present at the $5^{\prime}$ end of the intact CDNA which produced a single open reading frame in the original $\lambda$ gt 11 clone, and that the $5^{\prime} E c o$ RI site of this clone most likely represents an internal $E c o R I$ site in the cDNA. Attempts to find a longer cDNA for this gene in our laboratory have proven to be unsuccessful.

The predicted amino acid sequence encoded by this cDNA is also shown in Fig. 6. This sequence encodes a 475-amino acid polypeptide with a predicted molecular mass of 54,108 D. 57 basic and 66 acidic amino acid residues were found, predicting a net negative charge for this protein. This protein possesses two motifs which have been associated with nucleic acid and protein interactions. Multiple zinc finger motifs are located in the amino-terminal end of the polypeptide between residues 16 
1 GAATTCGGGCACACTGCTGTTTAACGGCACACTTGACAATGGCTTCAGCAGCACGCTTGACAATGATGTGGGAGGAGGTCACATGCCCT MetAlaSerAlaAlaArgLeuThrMetMetTrpGluGluValThrCysPro

90 ATCTGCCTGGACCCCTTCGTGGAGCCTGTGAGCATCGAGTGTGGCCACAGCTTCTGCCAGGAATGCATCTCTCAGGTTGGGAAGGTGGG IleCysLeuAspProPheValGluProValSerIleGluCysGlyHisSerPheCysGlnGluCysIleSerGlnValGlyLysGlyGly

180 GGCAGCGTCTGTCCTGTGTGCCGGCAGCGCTTTCTGCTCAAGAATCTCCGGCCCAATCGACAGCTAGCCAACATGGTGAACAACCTTAAA GlySerValCysProVa1CysArgGlnArgPheLeuLeuLysAsnLeuArgProAsnArgGlnLeuAlaAsnMetValAsnAsnLeuLys GAAATCAGCCAGGAGGCCAGAGAGgGCACACAGGgGaACGGTGTGCAGTGCATGGAGAGAGACTTCACCTGTTCTGTGAGAAGATGGG GluIleSerGlnGluAlaArgGluGlyThrGInGlyGluArgCysAlaValHisGlyGluArgLeuHisLeuPheCysGluLysAspGly 107

360 AAgGCCCTTTGCTGGGTATGTGCCCAGTCTCGGAAACACCGTGACCACGCCATGGTCCCTCTTGAGGAGGCTGCACAGGAGTACCAGGAG LysAlaLeuCysTrpVa1CysAlaGlnSerArgLysHisArgAspHisAlaMetValProLeuGluGluAlaAlaGlnGluTyrGlnGlu 137 AAgCTCCAGGTGGCATTAGGGGACTGAGAAGAAAGCAGGAGTTGGCTGAGAaGTTGGAaGTGGAAATTGCAATAAAGAGAGCAGACTGG LysLeuGlnVa1AlaLeuGlyGluLeuArgArgLysGlnGluLeuAlaGluLysLeuGluVa1GluIleAlaIleLysArgAlaAspTrp 167

540 AAGAAAACAGTGGAAACACAGAAATCTAGGATTCACGCAGAGTTTGTGCAGCAAAAAAACTTCCTGGTTGAAGAaGAACAGAGGCAGCTG LysLysThrValGluThrGlnLysSerArgIleHisAlaGluPheValGlnGlnLysAsnPheLeuValGluGluGluGlnArgGlnLeu 197

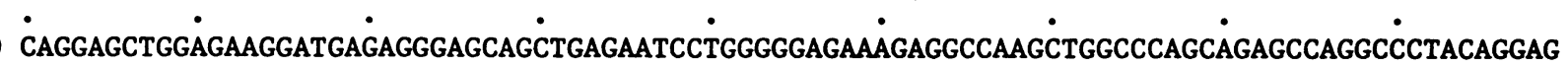
GlnGluLeuGluLysAspGluArgGluGlnLeuArgIleLeuGlyGluLysGluAlaLysLeuAlaGlnGlnSerGlnAlaLeuGlnGlu 227

720 CTCATCTCAGAGCTAGATCGAAGGTGCCACAGCTCAGCACTGGAACTGCTGCAGGAGGTGATAATTGTCCTGGAAAGAGTGAGTCCTGG LeuIleSerGluLeuAspArgArgCysHisSerSerAlaLeuGluLeuLeuGlnGluValIleIleValLeuGluArgSerG1uSerTrp 257

810 AACCTGAAGGACCTGGATATTACCTCTCCAGAACTCAGGAGTGTGTGCCATGTGCCAGGGCTGAGAaGATGCTGAGGACATGTGCAGTC AsnLeuLysAspLeuAspIleThrSerProGluLeuArgSerVa1CysHisVa1ProGlyLeuLysLysMetLeuArgThrCysAlaVal 287

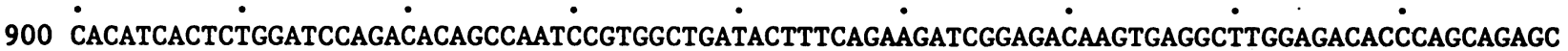
HisIleThrLeuAspProAspThrAlaAsnProTrpLeuIleLeuSerGluAspArgArgG1nVa1ArgLeuGlyAspThrG1nGlnSer 317

990 ATACCTGGAAATGAAGAGAGATTTGATAGTTATCCTATGGTCCTGGGTGCCCAGCACTTTCACTCTGGAAAACATTACTGGGAGGTAGAT IleProGlyAsnGluGluArgPheAspSerTyrProMetValLeuGlyAlaGlnHisPheHisSerGlyLysHisTyrTrpGluValAsp 347

1,080 GTGACAGGAAAGGAGGCCTGGGACCTGGGTGTCTGCAGAGACTCTGTGCGCAGGAAGGGGCACTTTTTGCTTAGTTCCAAGAGTGGCTTC ValThrGlyLysGluAlaTrpAspLeuGlyValCysArgAspSerValArgArgLysG1yHisPheLeuLeuSerSerLysSerG1yPhe 377

1,170 TGGACAATTTGGTTTGGAACAAACAAAAATATGAGGCTGGCACCTACCCCCAGACTCCCCTCCACCTTCAGGTGCCTCCATGCCAAGTT TrpThrIleTrpLeuTrpAsnLysG1nLysTyrGluAlaGlyThrTyrProGlnThrProLeuHisLeuGlnValProProCysG1nVal 407

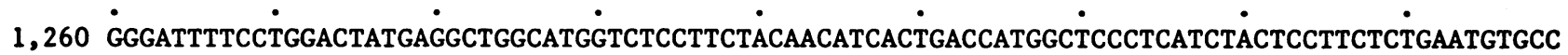
GlyIlePheLeuAspTyrGluAlaGlyMetValSerPheTyrAsnIleThrAspHisGlySerLeuIleTyrSerPheSerGluCysAla 437

1,350 TTTACAGGACCTCTGCGGCCCTTCTTCAGTCCTGGTTTCAATGATGGAGGAAAAAACACAGCCCCTCTAACCCTCTGTCCACTGAATATT PheThrGlyProLeuArgProPhePheSerProGlyPheAsnAspGlyGlyLysAsnThrAlaProLeuThrLeuCysProLeuAsnIle 467

1,440 GGATCACAAGGATCCACTGACTATTGATGGCTTTCTCTGGACACTGCCACTCTCCCCATTGGCACCGCTTCTCAGCCACAAACCCTGCCT GlySerGlnGlySerThrAspTyr *

1,530 CTTTTCCCCATGAACTCTGAACCACCTTTGTCTCTGCAGAGGCATCCGgATCCCAGCAAGCGAGCTTTAGCAGGGAAGTCACTTCACCAT 1,620 CAACATTCCTGCCCCAGATGGCTTTGTGATTCCCTCCAGTGAAGCAGCCTCCTTATATTTGGCCCAAACTCATCTTGATCAACCAAAAAC 1,710 ATGTTTCTGCCTTCTTTATGGGACTTAAGTTTTTTTTTTCTCCTCTCCATCTCTAGGATGTCGTCTTTGGTGAGATCTCTATTATATCTT 1,800 GTATGGTTTGCAAAAGGGCTTCCTAAAAATAAAAACCCGAATTC

Figure 6. The nucleotide and predicted amino acid sequence of the 52-kD Ro/SSA cDNA. The amino acid sequence was predicted from the nucleotide sequence of clone FI18.1 cDNA. Nucleotide sequence positions are numbered to the left of the figure, while amino acid sequence positions are numbered to the right. The positions of the zinc finger and leucine zipper motifs are described in the text. This sequence has been added to the GenBank nucleic acid sequence database, Los Alamos National Laboratory, NM, and has been assigned accession number M34551.

and 123. The amino acid sequence CXXC occurs four times, HXXC occurs twice, whereas CXXH and HXXH each occur once (where " $X$ " denotes any amino acid). The pairing of the cysteine and histidine residues in these putative metal binding structures is unclear. For example, Cys-36 may form a zinc finger pair either with His-33 or Cys-39. Similar sequences 
have been observed in DNA and RNA binding proteins (3639 ), and heterogeneity in the motif structure has been reported (40). A leucine zipper structure is also present in the 52-kD Ro/SSA protein between amino acids 211 and 232. The heptad repeat of leucine residues occurs three times in this 22-amino acid region. 12 of the 18 amino acids between these leucine residues are either uncharged polar residues, or charged amino acids, characteristic of other leucine zippers (41). Another leucine residue is present 14 amino acids in the $\mathrm{NH}_{2}$-terminal direction from Leu-211, although glutamic acid rather than leucine occurs at position 204. Again, a disproportionately high number of charged and glutamine residues occur in this region, suggesting that residues 197-210 may also represent a portion of this protein's leucine zipper. Leucine zippers are proposed to exist in $\alpha$-helical conformations which allow pairing between DNA-binding proteins $(41,42)$.

Predictions of hydrophobicity by the method of Kyte and Doolittle (43) and secondary structure by the method of Chou and Fasman (44) suggest a highly hydrophobic $\alpha$-helical region in the first 24 amino acids, an extended $\alpha$-helical hydrophilic region between amino acids 130 and 225 , and a hydrophobic carboxy-terminal 75 amino acids. Consistent with this prediction, the leucine zipper motif of the $52-\mathrm{kD}$ Ro/SSA protein occurs in a predicted $\alpha$-helical region. A potential $\mathrm{N}$-linked glycosylation site is located at amino acid 422. Although we are not aware of any data on whether Ro/SSA proteins are glycosylated, the absence of this posttranslational modification in $E$. coli suggests that glycosylation is not required for antigenic recognition by serum autoantibodies in the panel of lupus patients studied here.

A search through the Genbank (release 60.0) and EMBL (release 19.0) nucleic acid sequence data banks revealed only two sequences with moderate similarity to the $52-\mathrm{kD}$ cDNA sequence. The first 428 nucleotides in the coding region of the $52-\mathrm{kD} \mathrm{Ro} / \mathrm{SSA}$ gene are $62 \%$ identical to the $5^{\prime}$ portion of the mouse rpt-1 gene, whose product is involved in the downregulation of the IL-2 receptor (45). $54 \%$ of the nucleotides of this same region of the 52-kD Ro/SSA gene are identical to the 5 portion of the human rfp gene (46). (Two gaps were inserted in each comparison to optimize the alignment of these sequences.) Furthermore, the last 411 bases of the $52-\mathrm{kD} \mathrm{Ro} /$ SSA coding region are $64 \%$ identical with the $3^{\prime}$ portion of the coding region of the human rfp gene (after the introduction of three gaps to optimize sequence alignments). Little similarity was found in the middle portion of the coding regions of the latter two genes.

Searches for similarities between the predicted amino acid sequence of the 52-kD Ro/SSA protein and other protein sequences in the NBRF database (release 21.0) using the algorithm of Wilbur and Gipman (47) showed a significant match only with the predicted sequence of the human rfp transforming protein. The regions of similarity correspond to those identified above in the DNA. Alignment of these sequences reveals $42 \%$ identity in the $\mathrm{NH}_{2}$-terminal portions of these proteins, and $51 \%$ identity in their $\mathrm{COOH}$-terminal regions. Using the method of Gribskov and Burgess (48), the $\mathrm{NH}_{2}$-terminal residues of these proteins are $84 \%$ similar, while the $\mathrm{COOH}$-terminal amino acids are $86 \%$ similar. A comparison of the predicted amino acid sequences of the Ro/SSA 52-kD protein and the mouse rpt-1 protein using the method of Smith and Waterman (49) also revealed $47 \%$ identity ( $84 \%$ similarity) between the amino acids encoded by the $5^{\prime}$ portions of the coding regions described above.

The $\mathrm{NH}_{2}$-terminal portions of these three proteins contain zinc finger motifs in approximately their first 145 amino acid residues. Conservation of both amino acid sequence and spacing of these motifs was found (Fig. 7). His-100 of the 52-kD Ro/SSA sequence is absent in the other two proteins, suggesting that these residues may not form a zinc finger element. Because of the similarity between these zinc finger motifs, an additional search was made for similarities between the zinc finger region of the 52-kD Ro/SSA polypeptide and nine other proteins with zinc finger motifs. Of six comparisons with mammalian zinc finger containing proteins, similarity of the

\begin{tabular}{|c|c|c|}
\hline & 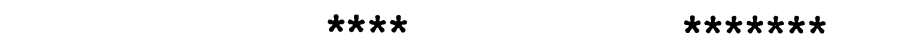 & $\star \star \star * *$ \\
\hline$k \mathrm{n} R$ & MASAARLTMMWEEVTCPICLDPFVEPVSIECGHSFCQECISQV & GKGGGSV CPVCRQ \\
\hline & ---GSVAECLQQ-T---V--QY-A--MMLD---NI-CA-LARC & W-TAETN-S-Q \\
\hline & $--E L L K----A D-N----R A-I T L N$ & NRNTD-KGN-- \\
\hline
\end{tabular}

\begin{tabular}{|c|c|c|c|}
\hline & & $(\star \star \star \star)$ & $\star \star \star \star$ \\
\hline & NRQLANMVNNLKEISQEAREGTQGER & CAVHGERLHLFCE & CAQSRK \\
\hline & $--\mathrm{H}---\mathrm{VTQLV}-\mathrm{QL}$ & $\mathrm{V}-\mathrm{EK}-\mathrm{R}-\mathrm{P}-\mathrm{K}-\mathrm{Y}-\mathrm{-}$ & $\mathrm{I}-\mathrm{V}--\mathrm{DR}--\mathrm{E}--\mathrm{G}-\mathrm{SVL}-$ \\
\hline & -EQKVNI & $--Q---K-R---$ & I--L-ER-QE--G-QTAL \\
\hline
\end{tabular}

\section{$52 \mathrm{kD}$ RO EYQEKLQVAL \\ RFP GFK-QI-NQ- \\ RPT-1 --K----G--}

Figure 7. Alignment of the amino-terminal portions of three proteins containing conserved zinc finger motifs. The first 143-amino acid residues of clone FI18.1 and 147 residues of the human rfp and mouse rpt-1 protein are shown. Asterisks indicate locations of potential zinc fingers. Spaces indicate positions where gaps were introduced to optimize alignment of the sequences. Dashes indicate identity to the residues of the 52KD Ro/SSA protein. 
Ro/SSA zinc finger region was found only with the rfp and rpt-1 proteins. Neither of two Drosophila nor one Xenopus zinc finger containing protein were similar to the Ro/SSA 52-kD zinc finger region. The spacing and amino acid conservation of this region between these three proteins suggests that they are evolutionarily and perhaps functionally related.

Interestingly, no significant homology was found between the $52-\mathrm{kD}$ Ro/SSA gene or protein and the three other sequences of the $60-\mathrm{kD}$ form of Ro/SSA. Two of the sequences for the $60-k D$ Ro/SSA gene differ only in their $3^{\prime}$ end $(17,18)$. A third $60-\mathrm{kD}$ Ro/SSA sequence shows no similarity to either of these sequences or to the 52-kD sequence reported here (19). Neither RNP-1 nor RNP-2 consensus binding sequences occur in the 52-kD Ro/SSA protein (50). It is clear from these data that the gene encoding the $52-\mathrm{kD}$ Ro/SSA polypeptide is unique from any of the $60-\mathrm{kD}$ Ro/SSA genes, and that the former polypeptide is not a transcriptionally or posttranslationally modified product of the $60-\mathrm{kD}$ gene.

\section{Discussion}

Two apparently identical human cDNA clones encoding the 52-kD Ro/SSA autoantigen were isolated from a $\lambda$ gt 11 expression library using an SLE patient serum which contains antibodies reactive with the $52-\mathrm{kD}$ Ro/SSA protein. This gene encodes a protein with two classes of nucleic acid binding structures, a zinc finger and a leucine zipper. Although fusion proteins with different DNA binding motifs have been described, they are the result of chromosomal translocations of different genes, and are apparently limited in expression to malignant cells $(51,52)$. Ro/SSA, on the other hand, is expressed in all cells examined to date. Therefore, it appears that the presence of these two nucleic acid binding motifs is unique to Ro/SSA.

The immunological identity of the antigens encoded by these cDNAs was established in several ways. First, IPTG-induced proteins in these clones reacted with affinity-purified antibodies from the 52-kD band of lymphocyte extracts, but not with those isolated from the $60-\mathrm{kD}$ Ro/SSA band. Secondly, antibodies affinity-purified from these clones specifcally recognized a 52-kD polypeptide in Western blots and immunoprecipitated all the Ro/SSA-associated hY RNAs in HeLa cells. The cDNA inserts from these two clones cross-hybridize, and their end terminal sequences are identical. These experiments demonstrate that cDNA FI18.1 and FI19.3 encode the 52-kD Ro/SSA antigen.

Because the amino-terminal sequence of the $52-\mathrm{kD}$ protein has not been determined, and the size of the full-length protein is closer to that of the 54-kD Ro/SSA protein, a formal possibility exists that this cDNA may encode the 54-kD form of the Ro/SSA protein, or a unique $60-\mathrm{kD}$ form of Ro/SSA. Three points argue against such an interpretation. First, the only common property of the sera reactive with the IPTG-induced proteins in these clones is that they have autoantibodies which bind to the 52-kD band in Western blots. In fact, autoantibodies in one patient's serum (MO) recognize only the 52-kD Ro/ SSA protein. Secondly, affinity-purified antibodies from IPTG-induced proteins in these clones bind to the 52- and not the $60-\mathrm{kD}$ band in Western blots of lymphocyte extracts. Finally, the 54-kD Ro/SSA protein has been detected only in red blood cells (15) and their immediate nucleated precursors (Y.
Itoh, unpublished results). Posttranslational cleavage of hydrophobic leader sequences in eukaryotic proteins is common. The predicted amino acid sequence of a recently reported 60 kD Ro/SSA protein includes 17 amino acids which are absent on the mature polypeptide (19). The 52-kD Ro/SSA protein reported here has a predicted amino-terminal hydrophobic region of $\sim 24$ amino acids (43). If these residues are removed in the formation of a mature 52-kD Ro/SSA polypeptide, a 452amino acid protein of $51,513 \mathrm{D}$ is predicted. Amino acid sequencing of purified 52- and 54-kD Ro/SSA polypeptides, or the eventual cloning of a gene which encodes the $54-\mathrm{kD}$ protein will be necessary to define the structural relationship between these two polypeptides and their posttranslational processing.

Since many of the lupus patients who produce anti-Ro/ SSA antibodies also make anti-La/SSB antibodies, the possibility that the cDNA described here encodes the La/SSB protein was also considered. We have ruled out this possibility in four ways. An absolute positive correlation was found between the presence of anti-52-kD Ro/SSA antibodies as detected by Western blot analyses and the ability of those patients' antibodies to react with IPTG-induced proteins of the recombinant clones. No association between the presence of anti-La/SSB antibodies and the specificity for this clone's proteins was observed. Second, anti-La/SSB antibodies affinity purified from the 45 $\mathrm{kD}$ region of a Western blot failed to bind to these clones. Third, affinity purified antibodies from these clones precipitated the Ro/SSA hY RNAs, but not any of the small RNAs associated with $\mathrm{La} / \mathrm{SSB}$, and finally, the nucleotide sequence of this clone is unrelated to that of $\mathrm{La} / \mathrm{SSB}$.

The zinc finger motifs found in the 52-kD Ro/SSA protein are characteristic of proteins which bind nucleic acids (36-39). The 52-kD Ro/SSA gene product is the first of which we are aware that contains both of these structures. It is of interest that the location, number, and spacing of the zinc fingers are so highly conserved in the 52-kD Ro/SSA, rfp, and rpt-1 proteins, but not in a number of other proteins containing zinc finger motifs. A portion of the rfp gene, designated "ret," was first identified after transformation of NIH 3T3 cells with segments of human DNA (53). Cloning of the gene from human cells indicated a portion of this gene undergoes translocation, and that this gene is expressed at high levels in mouse testis, embryos, and a variety of human and rodent tumor cell lines (46, 54). The function of the rfp gene product has not been identified. The rpt-1 protein has down-regulatory activity on the receptors for interleukin 2 in mice (45). While soluble IL-2 receptor levels have been reported to be abnormal in SLE patients (55-57), the mechanisms of regulating IL-2 receptor levels by this gene product have yet to be elucidated, and therefore, are unable to currently shed light on the function of the Ro/SSA molecule.

While hY RNAs immunoprecipitate with 52- and 60-kD Ro/SSA proteins, no information is available on whether the Ro/SSA ribonucleoprotein complexes bind to DNA, although the presence of Ro/SSA in both the nucleus and cytoplasm may suggest a role for binding to DNA as well as RNA $(58,59)$. However, several lines of evidence indicate that Ro/SSA particles are associated with one other ribonucleoprotein complex. $\mathrm{La} / \mathrm{SSB}$ has been found to be physically associated with Ro/ SSA complexes in Ouchterlony immunodiffusion assays (60). Immunoprecipitation of Ro/SSA particles with certain sera lacking anti-La/SSB specificity, as well as antibodies to hY5 containing Ro/SSA particles have each been shown to precipi- 
tate $\mathrm{La} / \mathrm{SSB}$ proteins $(61,62)$. In addition, a monoclonal antiLa/SSB antibody has been reported which binds to Ro/SSA particles (63). It has not been determined if the dual heptad repeat of leucine residues in $\mathrm{La} / \mathrm{SSB}$ is responsible for these protein's interaction (64). While both Ro/SSA and La/SSB particles have also been found in $45 \mathrm{~S}$ endoribonuclease VIIRNP complexes, the sites for interactions between subunits in these complexes remain undefined (65).

It is now clear that the $52-\mathrm{kD}$ form of Ro/SSA is not a differential transcriptional or posttranslational product of the $60-\mathrm{kD}$ Ro/SSA molecule. These proteins are encoded by distinct gene sequences. The fact that no cross-reaction has been observed with affinity-purified antibodies that recognize these proteins is consistent with this finding (16). Three reports now exist for genes which apparently encode the $60-\mathrm{kD}$ form of the Ro/SSA protein. Differences between the two most similar 60$\mathrm{kD} \mathrm{Ro/SSA}$ sequences may represent tissue specific isoforms, differential exon splicing, unusual allelic variants, or cloning artifacts $(17,18)$. The relationship between these and the third 60-kD Ro/SSA gene is not clear (19). However, the common characteristic of all these Ro/SSA proteins is their ability to physically associate with the small hY RNAs. Surprisingly, no similarity in the DNA or amino acid sequences was found between any of these $60-\mathrm{kD} \mathrm{Ro/SSA}$ clones and the 52-kD Ro/ SSA clone reported here. The deduced amino acid sequence of the 52-kD protein lacks similarity to other RNA binding proteins. While the RNP-binding consensus sequences defined by Dreyfus et al. (50) are not present in the 52-kD Ro/SSA antigen, they are also missing in one of the $60-\mathrm{kD}$ Ro/SSA sequence, the $\mathrm{D}$ protein of the $\mathrm{Sm}$ autoantigen, and in certain viral RNA binding proteins $(19,66,67)$. The heterogeneity of these sequences (50) may indicate either that other sequences serving the same function exist but are currently unrecognized, or that the hY RNA binding of Ro/SSA proteins is dependent on a particular tertiary configuration.

While the function of Ro/SSA is unknown, it is clear that considerable heterogeneity exists in these ribonucleoprotein complexes. At least two isoforms are present in nucleated and red blood cells, and tissue specific differences in Ro/SSA proteins have recently been identified (Itoh et al., manuscript submitted for publication). While the common feature of these proteins is their ability to bind hY RNAs, the number and form of these RNA molecules also varies between cells (15). Accordingly, functional differences in these complexes would not be unexpected. The physical heterogeneity of these Ro/SSA particles may, in part, explain the heterogeneity in the immune response to these complexes in patients with SLE and Sjogren's syndrome. Autoantibodies to Ro/SSA are associated with particular HLA serotypes and gene markers in these patients (11, 68-71). We have recently reported $\mathrm{T}$ cell receptor restriction fragment length proteins which are associated with the presence of anti-Ro/SSA antibodies (72). Since the antigenic portion of these complexes resides in the polypeptide, differences in the presence of particular anti-Ro/SSA antibodies between patients may be based on the ability of that patient's immune system to process and recognize epitopes which are unique to each form of the Ro/SSA polypeptides. Given the complexity of this antigenic system, a reevaluation of polymorphisms of the immune response genes of patients with anti-Ro/SSA antibodies is in order. The ability to purify different recombinant Ro/SSA proteins and use them in immunogenetic analyses may clarify the role of such genes in the generation of an im- mune response to Ro/SSA ribonucleoprotein complexes in patients with SLE and Sjogren's syndrome.

\section{Acknowledgments}

We greatfully acknowledge Dr. Morris Reichlin for the contribution of lupus patient serum samples and sharing of data not yet submitted for publication, Russell Rother for assistance in preparing bacteriophage lysogens, and both Laurie Soares and Sally Blechinger for expert technical assistance.

A portion of this work was supported by a contract from the Oklahoma Center for the Advancement of Science and Technology (OCAST), a grant from the Pittsburgh Supercomputer Center through the National Institutes of Health Division of Research Resources cooperative agreement U41 RR-04154 and grant AI-21568 from the National Institute of Allergy and Infectious Disease.

\section{References}

1. Clark, G., M. Reichlin, and T. B. Thomasi, Jr. 1969. Characterization of a soluble cytoplasmic antigen reactive with sera from patients with systemic lupus erythematosus. J. Immunol. 102:117-122.

2. Lerner, M. R., J. A. Boyle, J. A. Hardin, and J. A. Steitz. 1981. Two normal classes of small ribonucleoproteins detected by antibodies associated with lupus erythematosus. Science (Wash. DC). 211:400-402.

3. Reichlin, M. 1986. Significance of the Ro antigen system. J. Clin. Immunol. 6:339-348.

4. Yamagata, H., J. B. Harley, and M. Reichlin. 1984. Molecular properties of the Ro/SSA antigen and enzyme-linked immunosorbent assay for quantitation of antibody. J. Clin. Invest. 74:625-633.

5. Harley, J. B., E. L. Alexander, W. B. Bias, O. F. Fox, T. T. Provost, M. Reichlin, H. Yamagata, and F. C. Arnett. 1986. Anti-Ro/SSA and anti-La/SSB in patients with Sjogren's syndrome. Arthritis Rheum. 29:196-206.

6. Scott, J. S., P. J. Maddison, P. V. Taylor, E. Esscher, O. Scott, and R. P. Skinner. 1983. Connective tissue disease, antibodies to ribonucleoprotein and congenital heart block. N. Engl. J. Med. 309:209-212.

7. Taylor, P. V., K. F. Taylor, A. Norman, S. Griffiths, and J. S. Scott. 1988. Prevalence of maternal Ro(SSA) and $\mathrm{La}(\mathrm{SSB})$ autoantibodies in relation to congenital heart block. Br. J. Rheum. 27:128-132.

8. Maddison, P. J., and M. Reichlin. 1979. Deposition of antibodies to a soluble cytoplasmic antigen in the kidneys of patients with systemic lupus erythematosus. Arthritis Rheum. 22:858-863.

9. Wasicek, C. A., and M. Reichlin. 1982. Clinical and serological differences between systemic lupus erythematosus patients with antibodies to Ro vs. patients with antibodies to Ro and La. J. Clin. Invest. 69:835-843.

10. Smolen, J. S., C. Morimoto, A. D. Steinberg, A. Wolf, S. F. Schlossman, R. T. Steinberg, E. Penner, E. Reinherz, M. Reichlin, and T. M. Chused. 1985. Systemic lupus erythematosus: delineation of subpopulations by clinical, serologic and T cell subset analysis. Am. J. Med. Sci. 289:139-147.

11. Hamilton, R. G., J. B. Harley, W. B. Bias, M. Roebber, M. Reichlin, M. C. Hochberg, and F. C. Arnett. 1988. Two Ro (SS-A) autoantibody responses in systemic lupus erythematosus: correlation of HLA-DR/DQ specificities with quantitative expression of Ro (SS-A) autoantibody. Arthritis Rheum. 31:496505 .

12. Mond, C. B., M. G. E. Peterson, and N. F. Rothfield. 1989. Correlation of anti-Ro antibody with photosensitivity skin rash in systemic lupus erythematosus. Arthritis Rheum. 32:202-204.

13. Harley, J. B., A. L. Sestak, L. G. Willis, S. M. Fu, J. A. Hansen, and M. Reichlin. 1989. A model for disease heterogeneity in systemic lupus erythematosus: relationships between histocompatibility antigens, autoantibodies, lymphopenia and proteinurea. Arthritis Rheum. 32:826-836.

14. Ben-Chetrit, E., E. K. L. Chan, K. F. Sullivan, and E. M. Tan. 1988. A 52-kD protein is a novel component of the SS-A/Ro antigenic particle. J. Exp. Med. 167:1560-1571.

15. Rader, M. D., C. O'Brien, Y. Liu, J. B. Harley, and M. Reichlin. 1989. Heterogeneity of the Ro/SSA antigen: different molecular forms in lymphocytes and red blood cells. J. Clin. Invest. 83:1293-1298.

16. Itoh, Y., M. D. Rader, and M. Reichlin. 1990. Heterogeneity of the Ro/ SSA antigen and autoanti-Ro/SSA response: evidence for 4 antigenically distinct forms. Clin. Exp. Immunol. 81:45-51.

17. Deutscher, S. L., J. B. Harley, and J. D. Keene. 1988. Molecular analysis of the 60-kDa human Ro ribonucleoprotein. Proc. Natl. Acad. Sci. USA. 85:9479-9483.

18. Ben-Chetrit, E., B. J. Gandy, E. M. Tan, and K. F. Sullivan. 1989. Isolation and characterization of a cDNA clone encoding the 60-kD component of the human SS-A/Ro ribonucleoprotein autoantigen. J. Clin. Invest. 83:1284-1292. 
19. McCauliffe, D. P., F. A. Lux, T.-S. Lieu, I. Sanz, J. Hanke, M. M. Newkirk, L. L. Bachinski, Y. Itoh, M. J. Siciliano, M. Reichlin, et al. 1990. Molecula cloning, expression, and chromosome 19 localization of a human RO/SSA autoantigen. J. Clin. Invest. 85:1379-1391.

20. Tan, E. M., A. S. Cohen, J. F. Fries, A. T. Masi, D. J. McShane, N. F Rothfield, J. G. Schaller, N. Talal, and R. J. Winchester. 1982. The 1982 revised criteria for the classification of systemic lupus erythematosus. Arthritis Rheum 25:1271-1277.

21. Towbin, H., T. Staehelin, and J. Gordon. 1979. Electrophoretic transfer of proteins from polyacrylamide gels to nitrocellulose sheets: procedure and some applications. Proc. Natl. Acad. Sci. USA. 76:4350-4354.

22. Krohne, G., R. Stick, J. A. Kleinschmidt, R. Moll, W. W. Franke, and P Hausen. 1982. Immunological localization of a major karyoskeletal protein in nucleoli of oocytes and somatic cells of Xenopus laevis. J. Cell Biol. 94:749-754.

23. Forman, M. S., M. Nakamura, T. Mimori, C. Gelpi, and J. A. Hardin 1985. Detection of antibodies to small nuclear ribonucleoproteins and small cytoplasmic ribonucleoproteins using unlabeled cell extracts. Arthritis Rheum. 28:1356-1361.

24. Southern, E. M. 1978. Detection of specific sequences among DNA fragments separated by gel electrophoresis. J. Mol. Biol. 98:503-517.

25. Feinberg, A. P., and B. Vogelstein. 1983. A technique for radiolabeling DNA restriction endonuclease fragments to high specific activity. Anal. Biochem. 132:6-13.

26. Feinberg, A. P., and B. Vogelstein. 1984. Addendum: a technique for radiolabeling DNA restriction endonuclease fragments to high specific activity. Anal. Biochem. 137:266-267.

27. Sanger, F., A. R. Coulson, B. G. Barrell, A. J. H. Smith, and B. A. Roe 1980. Cloning in single-stranded bacteriophage as an aid to rapid DNA sequencing. J. Mol. Biol. 143:161-178.

28. Yanisch-Perron, C., J. Vieira, and J. Messing. 1985. Improved M13 phage cloning vectors and host strains: nucleotide sequences of the $\mathrm{M} 13 \mathrm{mp} 18$ and pUC19 vectors. Gene (Amst.). 33:103-119.

29. Sanger, F., S. Nicklen, and A. R. Coulsen. 1977. DNA sequencing with chain terminating inhibitors. Proc. Natl. Acad. Sci. USA. 74:5463-5467.

30. Tabor, S., and C. C. Richardson. 1987. DNA sequence analysis with a modified bacteriophage T7 DNA polymerase. Proc. Natl. Acad. Sci. USA. 84:4767-4771.

31. Dale, R. M. K., B. A. McClure, and J. P. Houchins. 1985. A rapid singlestranded cloning strategy for producing a sequential series of overlapping clones for use in DNA sequencing: application to sequencing the corn mitochondrial 18 S rDNA. Plasmid. 13:31-40.

32. Devereux, J., P. Haeberli, and O. Smithies. 1984. A comprehensive set of sequence analysis programs for the VAX. Nucleic Acids Res. 12:387-395.

33. Schwindinger, W. F., and J. R. Warner. 1984. DNA sequence analysis on the IBM computer. Nucleic Acids Res. 12:601-604.

34. Kozak, M. 1984. Compilation and analysis of sequences upstream from the translation start site in eukaryotic mRNAs. Nucleic Acids Res. 12:857-872.

35. Moldave, K. 1985. Eukaryotic protein synthesis. Annu. Rev. Biochem. 54:1109-1149.

36. Hanas, J. S., D. J. Hazuda, D. F. Bogenhagen, F. Y.-H. Wu, and C.-W. Wu. 1983. Xenopus transcription factor A requires zinc for binding to the $5 S$ RNA gene. J. Biol. Chem. 258:14120-14125.

37. Schiff, L. A., M. L. Nibert, M. S. Co, E. G. Brown, and B. N. Fields. 1988 Distinct binding sites for zinc and double-stranded RNA in the reovirus outer capsid protein sigma 3. Mol. Cell Biol. 8:273-283.

38. Miller, J., A. D. McLachlan, and A. Klug. 1985. Repetitive zinc-binding domains in the protein transcription factor IIIA from Xenopus oocytes. EMBO (Eur. Mol. Biol. Organ.) J. 4:1609-1614.

39. Evans, R. M., and S. M. Hollenberg. 1988. Zinc finger: gilt by association. Cell. $52: 1-3$.

40. Berg, J. M. 1986. Potential metal binding domains in nucleic acid binding proteins. Science (Wash. DC). 232:485-487.

41. Landschulz, W. H., P. F. Johnson, and S. L. McKnight. 1988. The leucine zipper: a hypothetical structure common to a new class of DNA binding proteins. Science (Wash. DC). 240:1759-1764.

42. Johnson, P. F., and S. L. McKnight. 1989. Eukaryotic transcriptional regulatory proteins. Annu. Rev. Biochem. 58:799-839.

43. Kyte, J., and R. Doolittle. 1982. A simple method for displaying the hydrophobic character of a protein. J. Mol. Biol. 157:105-132.

44. Chou, P. Y., and G. D. Fasman. 1978. Prediction of the secondary structure of proteins from their amino terminal sequence. Adv. Enzymol. 47:45-148.

45. Patarca, R., J. Schwartz, R. P. Singh, Q.-T. Kong, E. Murphy, Y. Anderson, F.-Y. W. Sheng, P. Singh, K. A. Johnson, S. M. Guarnagia, et al. 1988. rpt-1, an intracellular protein from helper/inducer $T$ cells that regulates gene expression of interleukin 2 receptor and human immunodeficiency virus type 1. Proc. Natl. Acad. Sci. USA. 85:2733-2737.

46. Takahashi, M., Y. Inaguma, H. Hiai, and F. Hirose. 1988. Developmentally regulated expression of a human "finger"-containing gene encoded by the 5 " half of the ret transforming gene. Mol. Cell Biol. 8:1853-1856.
47. Wilbur, W. J., and D. J. Lipman. 1983. Rapid similarity searches of nucleic acid and protein data banks. Proc. Natl. Acad. Sci. USA. 80:726-730.

48. Gribskov, M., and R. R. Burgess. 1986. Sigma factors from $E$. coli, phage SP01, and phage T4 are homologous proteins. Nucleic Acids Res. 14:6745-6763.

49. Smith, T. F., and M. S. Waterman. 1981. Comparison of biosequences. Adv. Appl. Math. 2:482-489.

50. Dreyfus, G., M. S. Swanson, and S. Pinol-Roma. 1988. Hetergeneous nuclear ribonucleoprotein particles and the pathway of mRNA formation. Trends. Biochem. Sci. 13:86-90.

51. Kamps, M. P., C. Murre, X.-H. Sun, and D. Baltimore. 1990. A new homeobox gene contributes the DNA binding domain of the $t(1 ; 19)$ translocation protein in pre-B ALL. Cell. 60:547-555.

52. Nourse, J., J. D. Mellentin, N. Galili, J. Wilkinson, E. Stanbridge, S. D. Smith, and M. L. Cleary. 1990. Chromosomal translocation $t(1 ; 19)$ results in synthesis of a homeobox fusion mRNA that codes for a potential chimeric transcription factor. Cell. 60:535-545.

53. Takahashi, M., and G. M. Cooper. 1987. Ret transforming gene encodes a fusion protein homologous to tyrosine kinase. Mol. Cell Biol. 7:1378-1385.

54. Greico, M., M. Santoro, M. T. Berlingieri, R. M. Melillo, R. Donghi, I. Bongarzone, M. A. Pierotti, G. D. Porta, A. Fusco, and G. Vecchio. 1990. PTC is a novel rearranged form of the ret proto-oncogene and is frequently detected in vivo in human thyroid papillary carcinomas. Cell 60:557-563.

55. Ishida, H., S. Kumagai, H. Umehara, H. Sano, Y. Tagaya, J. Yodoi, and H. Imura. 1987. Impaired expression of high affinity interleukin-2 receptor on activated lymphocytes from patients with systemic lupus erythematosus. J. Im munol. 139:1070-1074.

56. Semenzato, G., L. M. Bambara, D. Biasi, A. Frigo, F. Vinante, B. Zuppini, L. Trentin, C. Feruglio, M. Chilosi, and G. Pizzolo. 1988. Increased serum levels of soluble interleukin-2 receptor in patients with systemic lupus erythematosus and rheumatoid arthritis. J. Clin. Immunol. 8:447-452.

57. Tokano, Y., A. Murashima, Y. Takasaki, H. Hashimoto, K. Okumura, and S. Hirose. 1989. Relation between soluble interleukin 2-receptor and clinical findings in patients with systemic lupus erythematosus. Ann. Rheum. Dis. 48:803-809.

58. Lopes-Robles, E., R. Herrera-Esparza, and E Aralos-Diaz. 1986. Cellular localization of the Ro/SS-A antigen. Clin. Rheumatol. 5:33-38.

59. Lerner, M. R., and J. A. Steitz. 1981. Snurps and scyrps. Cell. 25:298-300

60. Eisenberg, R. A. 1985. Association between the Ro and La antigenic determinants: immunodiffusion analysis of human spleen extract. J. Immunol. 135:1707-1713.

61. Boire, G., and J. Craft. 1989. Biochemical and immunological heterogeneity of the Ro ribonucleoprotein particles: analysis with sera specific for the Ro hy 5 particle. J. Clin. Invest. 84:270-279.

62. Boire, G., and J. Craft. 1990. Human Ro ribinucleoprotein particles: characterization of native structure and stable association with the La polypeptide. J. Clin. Invest. 85:1182-1190.

63. Mamula, M. J., E. D. Silverman, R. M. Laxer, L. Bentur, B. Isacovics, and J. A. Hardin. 1989. Human monoclonal anti-La antibodies. The La protein resides on a subset of Ro particles. J. Immunol. 143:2923-2928.

64. Chamber, J. C., D. Kenan, B. J. Martin, and J. D. Keene. 1988. Genomic structure and amino acid sequence domains of the human La autoantigen. $J$. Biol. Chem. 263:18043-18051.

65. Bachmann, M., W. J. Mayet, H. C. Schroder, K. Pfeifer, K. H. Meyer zum Buschenfelde, and W. E. G. Muller. 1987. Identification of the Ro and La antigens in the endoribonuclease VII-ribonucleoprotein complex. Biochem. $J$. 243:189-194.

66. Rokeach, L. A., J. A. Haselby, and S. A. Hoch. 1988. Molecular cloning of a cDNA encoding the human Sm-D autoantigen. Proc. Natl. Acad. Sci. USA. 85:4832-4836.

67. Swanson, M. S., T. Y. Nakagawa, K. LeVan, and G. Dreyfus. 1987. Primary structure of human nuclear ribinucleoprotein particle $C$ proteins: conservation of sequence and domain structure in heterogeneous nuclear RNA, mRNA and pre-rRNA binding proteins. Mol. Cell Biol. 7:1731-1739.

68. Bell, D. A., and P. J. Maddison. 1980. Serologic subsets in systemic lupus erythematosus. Arthritis Rheum. 23:1268-1273.

69. Hochberg, M. C., R. E. Jr. Boyd, J. M. Ahearn, F. C. Arnett, W. B. Bias, T. T. Provost, and M. B. Stevens. 1985. Systemic lupus erythematosus: a review of clinico-laboratory features and immunogenetic markers in 150 patients with emphasis on demographic subsets. Medicine (Baltimore). 64:285-295.

70. Harley, J. B., M. Reichlin, F. C. Arnett, E. L. Alexander, W. B. Bias, and T. T. Provost. 1986. Gene interaction at HLA-DQ enhances autoantibody production in primary Sjogren's syndrome. Science (Wash. DC). 232:1145-1147.

71. Fujisaku, A., M. B. Frank, B. Neas, M. Reichlin, and J. B. Harley. 1990. HLA-DQ gene complementation and other histocompatibility relationships in man with the anti-Ro/SSA autoantibody response of systemic lupus erythematosus. J. Clin. Invest. 86:606-611.

72. Frank, M. B., R. McArthur, J. B. Harley, and A. Fujisaku. 1990. AntiRo(SSA) autoantibodies are associated with $\mathrm{T}$ cell receptor beta genes in systemic lupus erythematosus. J. Clin. Invest. 85:33-39. 